\title{
Relationship of index of cardiac electrophysiological balance with cigarette smoking in young adults.
}

\section{Genç Erişkinlerde Kardiyak Elektrofizyolojik Denge İndeksinin Sigara İçimi ile İlişsisi}

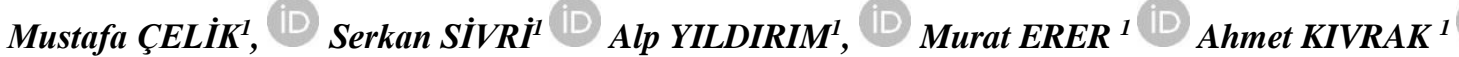

\section{$\underline{\ddot{Z Z}}$}

Amaç: Sigara içmek kardiyovasküler hastalıklar için güçlü bir risk teşkil etmekte olup mortalite ve morbidite ile ilişkilidir. Kardiyak elektrofizyolojik denge endeksi (iCEB), ventriküler aritmiyi öngörebilecek yeni ve basit bir EKG belirtecidir. QT, düzeltilmiş QT (QTc), Tp-Te aralığ 1 ve iCEB gibi yeni ventriküler repolarizasyon parametrelerinin sigara içen ve sigara içmeyen genç erkeklerde uzayıp uzamadığını araştırdık.

Araçlar ve Yöntem: Çalı̧̧mamız retrospektif olarak dizayn edilmiştir. Çalışmaya dahil edilen hastalar Haziran 2019 - Ekim 2019 tarihleri arasında hastanemiz kardiyoloji polikliniğine başvuran 20-30 yaşları arası erkeklerdi. Sigara içen (n: 91) ve sigara içmeyenler (n: 118) olarak 2 gruba ayrıldı. . QT aralı̆̆ı, QRS başlangıcı ile T dalgasının sonuna kadar QT aralığı ölçüldü. Bazett formülleri kullanılarak hesaplandı. Daha sonra, Tp-e / QTc, Tp-e / QT,QTc / QRS ve QT/QRS oranları hesaplandı. iCEB, yüzey EKG'sinden hesaplanan QT'nin QRS'ye (QT / QRS) oranı olarak hesaplandı.

Bulgular: QT, QT / QRS (iCEB), Tp-Te, QTc, QRS, QTc / QRS ve Tp-Te / QTe değerleri gruplar arasında anlamlı farkl1lı göstermedi. Sigara içenlerin beyaz küre ortalamaları ve lenfosit değerleri sigara içmeyenlere göre istatistiksel olarak anlamlıydı ( $p$ $<0.05)$

Sonuç: Çalışmamızda genç erkek sigara içicilerinde, sigara içmeyenlere göre T peak- T end, Tp-Te / QT, iCEB ve Tp-Te / QTc' nin değişmediğini gösterdik. Bildiğimiz kadarıyla, bu çalışma sigara içen gençlerde ICEB değerlerini araştıran ilk çalışmadır.

Anahtar Kelimeler: sigara; T peak-to-end; Tpe / QT

\section{ABSTRACT}

Purpose: Cigarette smoking constitutes a robust risk for cardiovascular diseases, and is associated with mortality and morbidity. Index of cardiac electrophysiological balance (iCEB), is calculated from surface ECG. It is a new and simple ECG marker capable of predicting ventricular arrhythmogenesis. We investigated whether QT, corrected QT (QTc), Tp-Te interval as well as new ventricular repolarization parameters such as iCEB are prolonged or not in the smoking and non-smoking young males.

Materials and Methods: Our study was designed retrospectively. The included patients were between 20-30 of age-old males who admitted to our hospital's cardiology outpatient clinic between June 2019 and October 2019. They were divided into 2 groups as smokers (n:91) and non-smokers (n:118). From the beginning of the QRS complex to the end of the T wave, QT interval was measured and QT interval was corrected using the Bazett's formulae. Then, QTc/QRS, Tp-e/QTc, QT/QRS, and Tp-e/QT ratios were calculated. iCEB, namely the ratio of QT to QRS (QT/QRS) was calculated from surface ECG.

Results: QT/QRS (iCEB), Tpeak-Tend, QTc, Tp-Te/QT, QT, Tp-Te/QTc, QRS, and QTc/QRS values were not significantly different between the groups. The mean white Blood Cell (WBC) and lymphocyte counts of the smokers were higher compared to non-smokers, which was statistically significant $(\mathrm{p}<0.05)$.

Conclusion: We showed that Tp-Te interval, iCEB, Tp-Te/QT and Tp-Te/QTc did not change significantly in the otherwise healthy young male smokers as compared to the nonsmokers. As far as we know, this study is the first to investigate the ICEB values in young smoker subjects.

Key Words: cigarette, T peak-to-end; Tpe/QT

Received:28.04.2020; Accepted: 08.06.2020

${ }^{1}$ Department of Cardiology, Kirsehir Ahi Evran University Training and Research Hospital, Kirsehir, Turkey

Corresponding Author: Mustafa ÇELIK, Department of Cardiology, Ahi Evran University Training and Research Hospital, Kirsehir, Turkey. e-posta: muscelik50@gmail.com

How to cite: Çelik M, Sivri S, Yıldırım A, Erer M, Kıvrak A. Relationship of index of cardiac electrophysiological balance with cigarette smoking in young adults. Ahi Evran Med J. 2020;4(3):60-65 


\section{INTRODUCTION}

Cigarette smoking constitutes a robust risk for cardiovascular diseases, and is associated with mortality and morbidity. ${ }^{1}$ The studies showed that smoking cessation reduces all-cause mortality by $36 \%$ in smoking patients with coronary artery disease $(\mathrm{CAD}){ }^{2}$ During smoking, nicotine is released into circulation and causes increased catecholamine levels in plasma, leading to an elevated heart rate and blood pressure. Therefore, myocardial work load and oxygen requirement may increase, and cardiac arrhythmias may develop. ${ }^{3}$

Animal experiments showed that nicotine prolongs interatrial conduction time and effective refractory period, causing supraventricular arrhythmia, atrio-ventricular junctional arrhythmia and ventricular arrhythmia.$^{4,5}$

The interval between the QRS onset and T-wave end in the surface electrocardiogram (ECG) reflects ventricular depolarization and repolarization. Furthermore, the end of $\mathrm{T}$-wave (Tp-Te) and the interval between the peak was suggested as an predictor of the total dispersion of repolarization, and any prolongation in Tp-Te interval was found to be associated with ventricular arrhythmia. ${ }^{6}$ Additionally, corrected QT interval (QTc) and QT interval (QT) may also indicate myocardial repolarization in surface ECG.

Tp-Te/QTc and Tp-Te/QT ratios are the other markers reflecting ventricular arrhythmogenesis.$^{7}$ Index of cardiac electrophysiological balance (iCEB), the ratio of QT to QRS (QT/QRS), is calculated from surface ECG. It is a new and simple ECG marker capable of predicting ventricular arrhythmogenesis. ${ }^{8}$ In the present study, we investigated whether QT, corrected QT (QTc), Tp-Te interval as well as new ventricular repolarization parameters such as iCEB are prolonged or not in the smoking and non-smoking young males.

\section{METHODS}

\section{Study Population}

Our study was designed retrospectively. The included patients were between 20-30 of age males who admitted to our hospital's cardiology outpatient clinic for pre-military examination between June 2019 and October 2019 without any cardiac pathology. They were divided into 2 groups as smokers (n:91) and nonsmokers(n:118). Routine ECG was performed after the patients rested in the supine position for 5 minutes. Clinical follow-up has not been performed in terms of ventricular arrhythmia. The exclusion criteria were as follows: Detection of any arrhythmia in ECG, use of antiarrhythmic drugs, moderate-severe cardiac valvular disease, hepatic and renal dysfunction, active infection, hypertension (HT), coronary artery disease (CAD), diabetes (DM), and morbid obesity.

Fasting blood samples were drawn at admission for the measurement of complete blood count (CBC) and blood chemistry. In addition, every participant underwent a comprehensive transthoracic echocardiographic examination (Toshiba, Version: 3.0.2.0003, Andover, USA). All the participants underwent a scrutiny including and a thorough physical examination, a detailed medical history and recording baseline demographic features including age, coronary arterial disease, sex, diabetes mellitus, hypertension, peripheral arterial disease, chronic obstructive pulmonary disease, smoking habit, chronic obstructive pulmonary disease. Either a written or an oralwitnessed informed consent was taken from all subjects. Our study was approved by the local ethics committee (Approvel Number: 2019-20/192 Date:26/11/2019) and was performed incompliance with the set of principles by the Declaration of Helsinki.

\section{ECG Examination}

12-lead ECGs were obtained from all participants with 10 $\mathrm{mm} / \mathrm{mV}$ and $25 \mathrm{~mm} / \mathrm{s}$ paper speed amplitude via a standard device (MAC 1600, $8400 \mathrm{~W}$, Milwaukee, USA) in supine position. ECG papers were then transferred to computer and evaluated on a personalized computer with x400 magnification. ECG measurement values were transferred to the database by averaging 3 consecutive beats on precordial lead V5.${ }^{9,10}$ From the beginning of the QRS complex to the end of the T wave, QT interval was measured and QT interval was corrected using the Bazett's formulae. ${ }^{11}$ Also, Tp-Te interval was accepted as the time interval between the peak of T-wave and intersection point between the isoelectric line and tangent of downsloping T-wave. ${ }^{12}$ Then, Tp-Te/QTc and Tp-Te/QT were 
calculated. All the measurements were performed by two cardiologists blinded to the study data. Index of cardiac electrophysiological balance (iCEB), namely the ratio of QT to QRS (QT/QRS) was calculated from surface ECG.

\section{Statistics}

The study data was analyzed using SPSS version 21.0 software for Windows (IBM SPSS Statistics for Windows version 21.0. (IBM Corp, Armonk, New York)

The assumption of normality for quantitative variables was tested by Shapiro-Wilk and Kolmogorov-Smirnov tests. Descriptive statistics of variables were given as mean干standard deviation or median (interquartile ranges at the 25th and 75th percentiles, IQR). Independent-t test or Mann-Whitney-U were used according to the proposed assumptions for univariate analysis of the variables in the study. A $p$ value of $<0.05$ was accepted to be of statistical significance.

\section{RESULTS}

Whole study group was composed of male subjects. 118 of which were in the non-smokers group, while 91 were in the smokers group. The average smoking duration in the smokers group is 8.52 packs/year. Laboratory, clinical and echocardiographic results were presented in Table 1-2.

Age distribution was homogeneous between the groups ( $p>0.05$ ). Glucose values of non-smokers were found to be greater compared with the smoker group but the difference was statistically insignificant $(p>0.05)$. The mean white Blood Cell (WBC) count of the smokers were higher compared with non-smokers, which was statistically significant $(p<0.01)$. The mean neutrophil counts of the smokers (4.46 $\mp 1.46)$ were higher compared to those of non-smokers $(4.06 \mp 1.21)$. The difference was statistically significant between two groups $(\mathrm{p}<0.05)$. The lymphocyte values of the smokers were also higher compared to the non-smokers $(\mathrm{p}<0.05)$.
Table 1. Clinical characteristics, laboratory, and echocardiographic results of the study population.

\begin{tabular}{|c|c|c|c|}
\hline Variables & $\begin{array}{l}\text { Non-smokers } \\
(\mathrm{n}=118)\end{array}$ & $\begin{array}{l}\text { Smokers } \\
(\mathrm{n}=91)\end{array}$ & $p$ value \\
\hline Age(years) & $25.67 \mp 1.83$ & $26.0 \mp 1.85$ & 0.200 \\
\hline Glukoz(mg/dL) & $89.01 \mp 9.34$ & $87.60 \mp 6.67$ & 0.224 \\
\hline $\mathrm{GFR}(\mathrm{mL} / \mathrm{min})$ & $116(108 \sim 121)$ & $117(108 \sim 122)$ & 0.279 \\
\hline AST(U/L) & $19(17 \sim 22)$ & $18(16 \sim 21)$ & 0.195 \\
\hline $\operatorname{ALT}(\mathrm{U} / \mathrm{L})$ & $18(13 \sim 23.5)$ & 19(15 23) & 0.406 \\
\hline $\mathrm{CK}(\mathrm{U} / \mathrm{L})$ & 129.5(98 191.75) & 148(107 225) & 0.201 \\
\hline $\mathrm{CRP}(\mathrm{mg} / \mathrm{L})$ & $0.06(0.04 \sim 0.13)$ & $0.09(0.05 \sim 0.17)$ & 0.068 \\
\hline $\begin{array}{l}\text { Sedimentation } \\
\text { ( } \mathrm{mm} / \text { hour })\end{array}$ & $5(3 \sim 5)$ & $5(3 \sim 6)$ & 0.935 \\
\hline TSH(IU/mL) & $1.52(1.15 \sim 2.0)$ & $1.46(1.16 \sim 1.99)$ & 0.837 \\
\hline $\mathrm{WBC}(\mathrm{K} / \mathrm{uL})$ & $6.87(5.89 \sim 7.72)$ & $7.46(6.47 \sim 8.86)$ & 0.003 \\
\hline HGB (gr/dL) & $15.45 \mp 0.97$ & $15.49 \mp 1.56$ & 0.815 \\
\hline RDW, \% & $12.52 \mp 1.33$ & $12.62 \mp 1.64$ & 0.608 \\
\hline $\operatorname{PLT}(\mathrm{K} / \mathrm{uL})$ & $250.75 \mp 52.09$ & $249.05 \mp 54.88$ & 0.819 \\
\hline $\mathrm{NEU}(\mathrm{K} / \mathrm{uL})$ & $4.06 \mp 1.21$ & 4.46干1.46 & 0.030 \\
\hline $\operatorname{LYM}(\mathrm{K} / \mathrm{uL})$ & $2.05(1.76 \mp 2.42)$ & $2.25(1.90 \mp 2.75)$ & 0.025 \\
\hline MPW(fL) & 10.30(9.80干11.0) & $10.40(9.811 .20)$ & 0.584 \\
\hline PCT, \% & $0.25 \mp 0.04$ & $0.25 \mp 0.05$ & 0.919 \\
\hline \multirow{2}{*}{$\begin{array}{l}\text { LVEF,\% } \\
\text { Cigarette smoking } \\
\text { (pack-years) }\end{array}$} & $64(62 \sim 65)$ & $65(63 \sim 67)$ & 0.150 \\
\hline & ------- & $8.52 \mp 2.33$ & $<0.001$ \\
\hline \multicolumn{4}{|c|}{$\begin{array}{l}\text { GFR, Glomerular filtration rate; ALT, Alanine Amino } \\
\text { transferase; AST, Aspartate amino transferase; CK, creatine } \\
\text { kinase; CRP,C-reactive protein; TSH, Thyroid stimulating } \\
\text { hormone; WBC, White Blood Cell; HGB, Hemoglobin; RDW, } \\
\text { Red Cell Distribution Width; PLT ,Platelet; NEU, Neutrophil; } \\
\text { LYM, Lymphocytes ;MPW, mean platelet volume; PCT, } \\
\text { Plateletcrit ;LVEF, left ventricle ejection fraction }\end{array}$} \\
\hline
\end{tabular}

QT,QT/QRS (iCEB), Tp-Te, QRS Tp-Te/QT, Tp-Te/QTc,

QTc and QTc/QRS values were not significantly different between the groups.

Table 2. Electrocardiographic results of the study population.

\begin{tabular}{llll} 
Variables & $\begin{array}{l}\text { Non-smokers } \\
(\mathbf{n}=\mathbf{1 1 8})\end{array}$ & $\begin{array}{l}\text { smokers } \\
(\mathbf{n}=91)\end{array}$ & $\begin{array}{l}\boldsymbol{p} \\
\text { value }\end{array}$ \\
\hline QRS(ms) & $91.79 \mp 11.64$ & $91.94 \mp 12.42$ & 0.929 \\
QT (ms) & $325.39 \mp 24.60$ & $326.0 \mp 22.88$ & 0.865 \\
TP-e (ms) & $70.84 \mp 11.90$ & $69.35 \mp 11.05$ & 0.362 \\
HR(beats/min) & $84.19 \mp 14.17$ & $85.58 \mp 12.80$ & 0.469 \\
QTc(ms) & $381.93 \mp 24.32$ & $385.64 \mp 23.23$ & 0.270 \\
TP-e/QT & $0.21 \mp 0.034$ & $0.21 \mp 0.034$ & 0.345 \\
TP-e/QTc & $0.18 \mp 0.02$ & $0.17 \mp 0.02$ & 0.140 \\
QT/QRS & $3.59 \mp 0.49$ & $3.60 \mp 0.49$ & 0.939 \\
QTc/QRS & $4.22 \mp 0.57$ & $4.21 \mp 0.73$ & 0.933 \\
\hline
\end{tabular}

HR, Heart rate;Tp-e, T peak and end interval;QTc, Corrected QT interval;ms, millisecond 


\section{DISCUSSION}

In this study performed on smoker and non-smoker young males, no significant inter-group differences were documented concerning such ECG parameters as QT, QTc, Tp-Te/QTc ,Tp-Te and Tp- Te/QT, QT/QRS, QTc/QRS indicating ventricular repolarization. Smoking is among the well-established risk factors for cardiovascular illnesses such as diabetes mellitus and hypertension, and causes death worldwide. ${ }^{13}$ It causes cardiovascular adverse events by decreasing the oxygen transport capability of blood, increasing the workload of myocardium, enhancing catecholamine release and inducing endothelial cell dysfunction. ${ }^{14}$ Nicotine, carbon monoxide (CO) and tar are among the toxic chemicals of cigarette. More specifically, nicotine may lead to cardiac rhythm disorders including atrial fibrillation, transient sinus arrest, sinus tachycardia, bradycardia and ventricular tachyarrhythmia. ${ }^{15}$

$\mathrm{Tp}-\mathrm{Te} / \mathrm{QT}$ and $\mathrm{Tp}-\mathrm{Te}$ ratio have been suggested to be among novel ECG parameters indicating dispersion of ventricular repolarization. Previous data suggested that prolonged Tp-Te interval is related with sudden death and ventricular arrhythmia. ${ }^{16-19}$

Moreover, some other electrophysiological studies showed that a prolonged $\mathrm{Tp}-\mathrm{Te}$ is associated with ventricular arrhythmias induction. ${ }^{17,18}$ Greater Tp-Te/QT ratios were reported to be associated with cardiac arrhythmias in diverse clinical scenarios, such as acute myocardial infarction, hypertrophic cardiomyopathy and Brugada syndrome. ${ }^{17-19}$ Ilgenli at al. reported that exposure to chronic cigarette smoke was associated with a prolonged $\mathrm{Tp}$-Te, and increased $\mathrm{Tp}-\mathrm{Te} / \mathrm{QTc}$ and $\mathrm{Tp}$ Te/QT. This study suggested that there might be a correlation between smoking and ventricular repolarization and abnormal ventricular repolarization in long-term heavy smokers may explain the risk of increased cardiovascular events.$^{20}$ However, a total of 47 male and female patients were included, and the mean age of the patients was 42 years. There are significant differences between our study and this study in terms of the number of study population and mean age. The mean age of our study was 25.8 years. Comparing two studies, we may suggest that ventricular repolarization parameters are not affected by smoking at younger ages, however, these parameters are gradually affected at older ages, and the risk of cardiovascular events and arrhythmia is increased.

In a study on smoker adolescents performed by Kayalı et $\mathrm{al}$, it was found that cigarette prolonged Tp-Te, Tp-Te/QTc and $\mathrm{Tp}-\mathrm{Te} / \mathrm{QT}$ ratios. They concluded that smoking could be associated with arrhythmias. The results of that study did not correspond to the results of our study. In the study of Kayalı et al, the study population consisted of 87 subjects and the mean age was 17 years. The number of cigarettes per day and years of smoking, Tpe interval, Tpe/QTc andTpe/QT ratios were also different compated to the current study ${ }^{21}$ This study is also contradicted with the study of Hallstrom et al showing that smoking and cardiovascular events are dose-dependent.$^{22}$ Taşolar et al observed that cTp-Te, Tp-Te/QTc or Tp-Te/QT ratios were elevated in smokers, and these elevations showed significant correlation with the amount of cigarettes. ${ }^{23}$ The mean age of the subjects included in the study of Taşolar et al was 35 years. We may suggest that ventricular repolarization parameters that may cause ventricular arrhythmias in the early period are not prolonged, and the risk of cardiovascular events may increase as the amount and duration of smoking increases. $\mathrm{ICEB}$ is a non-invasive parameter which indicates ventricular proarrhythmic risk. Since QT interval represents ERP and duration of QRS complex changes with conduction velocity, iCEB may give insight concerning both of cardiac depolarization and repolarization. Hence, iCEB can predict more precisely the cardiac proarrhythmic risk compared to sole QT interval or transmural T-wave dispersion both of which points out to the instabilities only in cardiac repolarization. ${ }^{24}$ Yumurtac1 et al showed in the patients with acute myocarditis that Tp-Te, iCEB, Tp-Te/QT and Tp-Te/QTc were significantly greater in subjects with cardiac arrhythmia than those who did not develop arrhythmia. ${ }^{25}$ Furthermore, another study we conducted showed that iCEB calculated following hemodialysis were significantly greater in the end-stage renal failure patients, and this might be associated with ventricular arrhythmia. ${ }^{26}$ Besides, Özdemir et al showed that ICEB changed in individuals with smoking habits. ${ }^{2}$ 
Our study should be assessed in the light of a number of limitations. First, our study population is relatively small and it is a single-center study. Multi-center studies with larger populations are needed. The second important limitation is that only young males were included in the study group. Third, long-term outpatient ECG monitoring (ECG Holter) methods could be used to evaluate the relationship between arrhythmia and the studied ventricular repolarization parameters. The Fourth important limitation is that measurements were manually performed instead of computer-aided calculations. Automated measuring systems have been developed for QT measurement; however, there are current problems with these systems.$^{28}$ Manual identification of end of the T-wave may possess low reproducibility, and be problematic and cardiologist-dependent. For this reason, automated softwares should be preferred.

To sum up, in this study, we showed that iCEB, Tp-Te,Tp$\mathrm{Te} / \mathrm{QTc}$ or Tp-Te/QT did not change significantly in the otherwise healthy young male smokers compared to the nonsmokers. As far as we know, this study is the first to investigate ICEB values in smoker subjects. Interpreting our study results together with the current ones, we suggest that ventricular repolarization is not impaired in smokers younger than $\sim 25$ years old, while individuals older that 35 years old may have prolonged ventricular repolarization parameters and an elevated risk of adverse cardiovascular arrhythmic events. In conclusion, the sooner we quit smoking, the less adverse effects associated with cardiac arrhythmia would occur.

\section{Conflict of Interests}

The authors declare that there is no conflict of interests.

\section{REFERENCES}

1. Tonstad S, Andrew Johnston J. Cardiovascular risks associated with smoking: a review for clinicians. Eur J Cardiovasc Prev Rehabil. 2006;13(4):507-514.

2. Critchley JA, Capewell S. Mortality risk reduction associated with smoking cessation in patients with coronary heart disease: a systematic review. JAMA. 2003;290(1):86-97.

3. Schrör K, Zimmermann KC, Tannhäuser R. Augmented myocardial ischaemia by nicotine--mechanisms and their possible significance. Br J Pharmacol. 1998;125(1):79-86.

4. Mehta MC, Jain AC, Mehta A, Billie M. Cardiac Arrhythmias Following Intravenous Nicotine: Experimental Study in Dogs. J Cardiovasc Pharmacol Ther.
1997;2(4):291-298.

5. Hayashi H, Omichi C, Miyauchi Y, Mandel WJ, Lin SF, Chen PS, et al. Age-related sensitivity to nicotine for inducible atrial tachycardia and atrial fibrillation. Am J Physiol Heart Circ Physiol. 2003;285(5):2091-2098.

6. Kors JA, Ritsema van Eck HJ, van Herpen G. The meaning of the Tp-Te interval and its diagnostic value. J Electrocardiol. 2008;41(6):575-580.

7. Gupta P, Patel C, Patel H, Narayanaswamy S, Malhotra B, Green JT, et al. T(p-e)/QT ratio as an index of arrhythmogenesis. J Electrocardiol. 2008;41(6):567-574.

8. Robyns T, Lu HR, Gallacher DJ, Garweg C, Ector J, Willems R, et al. Evaluation of Index of CardioElectrophysiological Balance (iCEB) as a New Biomarker for the Identification of Patients at Increased Arrhythmic Risk. Ann Noninvasive Electrocardiol. 2016;21(3):294304

9. Castro-Torres Y, Carmona-Puerta R, Katholi RE. Ventricular repolarization markers for predicting malignant arrhythmias in clinical practice. World J Clin Cases. 2015;3(8):705-720.

10. Castro Hevia J, Antzelevitch C, TornésBárzaga F, et al. Tpeak-Tend and Tpeak-Tend dispersion as risk factors for ventricular tachycardia/ventricular fibrillation in patients with the Brugada syndrome. J Am Coll Cardiol. 2006;47(9):1828-1834.

11. Haarmark C, Graff C, Andersen MP, et al. Reference values of electrocardiogram repolarization variables in a healthy population. J Electrocardiol. 2010;43(1):31-39.

12. Charbit B, Samain E, Merckx P, Funck-Brentano C. QT interval measurement: evaluation of automatic QTc measurement and new simple method to calculate and interpret corrected QT interval. Anesthesiology. 2006;104(2):255-260.

13. Perou R, Bitsko RH, Blumberg SJ, et al. Centers for Disease Control and Prevention (CDC). Mental health surveillance among children--United States, 2005-2011. MMWR Suppl. 2013;62(2):1-35.

14. Benowitz NL, Hansson A, Jacob P 3rd. Cardiovascular effects of nasal and transdermal nicotine and cigarette smoking. Hypertension. 2002;39(6):1107-1112.

15. D'Alessandro A, Boeckelmann I, Hammwhöner M, Goette A. Nicotine, cigarette smoking and cardiac arrhythmia: an overview. Eur J Prev Cardiol. 2012;19(3):297-305.

16. Kors JA, Ritsema van Eck HJ, van Herpen G. The meaning of the Tp-Te interval and its diagnostic value. J Electrocardiol. 2008;41(6):575-580.

17. Smetana P, Schmidt A, Zabel M, Hnatkova K, Franz M, Huber K, et al. Assessment of repolarization heterogeneity for prediction of mortality in cardiovascular disease: peak to the end of the $\mathrm{T}$ wave interval and nondipolar repolarization components. J Electrocardiol. 2011;44(3):301-308.

18. Erikssen G, Liestø1 K, Gullestad L, Haugaa KH, Bendz B, Amlie JP. The terminal part of the QT interval ( $\mathrm{T}$ peak to $\mathrm{T}$ end): a predictor of mortality after acute myocardial infarction. Ann Noninvasive Electrocardiol. 2012;17(2):85-94.

19. Panikkath R, Reinier K, Uy-Evanado A, Teodorescu C, Hattenhauer J, Mariani R, et al. Prolonged Tpeak-to-tend interval on the resting ECG is associated with increased risk of sudden cardiac death. Circ Arrhythm Electrophysiol. 2011;4(4):441-447.

20. İlgenli,T.F, Tokatlı A, Akpınar O, Kılıçaslan F. The Effects of Cigarette Smoking on the Tp-e Interval, Tp-e/QT Ratio and Tp-e/QTc RatioAdv Clin Exp Med. 2015;24(6):973978

21. Kayali S, Demir F. The effects of cigarette smoking on ventricular repolarization in adolescents. Einstein (Sao Paulo). 2017;15(3):251-255

22. Hallstrom AP, Cobb LA, Ray R. Smoking as a risk factor for recurrence of sudden cardiac arrest. N Engl J Med. 1986;314(5):271-275.

23. Taşolar H, Ballı M, Bayramoğlu A, et al. Effect of smoking on Tp-e interval, Tp-e/QT and Tp-e/QTc ratios as indices of ventricular arrhythmogenesis. Heart Lung Circ. 
2014;23(9):827-832.

24. Lu HR, Yan GX, Gallacher DJ. A new biomarker--index of cardiac electrophysiological balance (iCEB) plays an important role in drug-induced cardiac arrhythmias: beyond QT-prolongation and Torsades de Pointes (TdPs). J Pharmacol Toxicol Methods. 2013;68(2):250-259.

25. Yumurtacı O, Kurt C, Ucar FM, Ozturk C. Usefulness of electrocardiographic markers to predict ventricular arrhythmia in acute myocarditis. Turkish Med Stud J. 2017;4(1):6-10.

26. Sivri S, Çelik M. Evaluation of index of cardiac- electrophysiological balance before and after hemodialysis in patients with end-stage renal disease. J Electrocardiol. 2019;54:72-75.

27. Özdemir L, Sökmen E. Effect of habitual cigarette smoking on the index of cardiac electrophysiological balance in apparently healthy individuals. J Electrocardiol. 2020;59:41-44.

28. Grasser EK, Ernst B, Thurnheer M, Schultes B. QT Interval Shortening After Bariatric Surgery Depends on the Applied Heart Rate Correction Equation. Obes Surg. 2017;27(4):973-982. 